Article

\title{
Challenges in Adapting Sustainable City Solutions from Finland to Different Contexts Worldwide: A Libyan Case Study
}

\author{
Carmen Antuña-Rozado ${ }^{1, *(1)}$, Justo García-Navarro ${ }^{2}$ and Pekka Huovila ${ }^{3}$ \\ VTT Technical Research Centre of Finland Ltd., PO Box 1000, FI-02044 VTT Espoo, Finland \\ 2 Research Group on Sustainability in Construction and Industry giSCI-UPM, Universidad Politécnica de \\ Madrid, ETSIA—Ciudad Universitaria, s/n, 28040 Madrid, Spain; justo.gnavarro@upm.es \\ 3 Sustainability Laboratory Oy, 00640 Helsinki, Finland; pekka.huovila@slab.fi \\ * Correspondence: carmen.antuna@vtt.fi; Tel.: +358-40-199-3522
}

Received: 21 March 2019; Accepted: 13 May 2019; Published: 17 May 2019

\begin{abstract}
The EcoCity concept presented here has been designed in Finland and improved through collaboration with local partners and stakeholders to adapt to varying contexts while trying to provide solutions for the improvement of human settlements around the world, particularly in the Global South. Supported by specific methodologies and effective facilitation processes and skills, also developed by VTT Technical Research Centre of Finland Ltd. (VTT), it provides a structured yet flexible framework for conducting the complex dialogue leading to ecocity implementation, the importance of which is typically overlooked. This article discusses the theoretical underpinnings of the concept in relation to the general ecocity debate, as well as its main historical influences linked to the Finnish urban development tradition. The process thus enabled is illustrated by a Libyan case study.
\end{abstract}

Keywords: EcoCity; capacity building; Eco-Viikki; local adaptation; New Urban Agenda (NUA); participation; sustainable urban development

\section{Introduction}

According to the United Nations Population Division, 54.5 per cent of the world's population were living in urban settlements in 2016, whereas by 2030 it is expected that 60 per cent of people globally will live in urban areas with one in every three people living in cities of at least half a million inhabitants [1]. Urbanization poses enormous challenges for cities around the world, particularly in the Global South: adequate infrastructure, affordable housing, public transport, decent employment, access to services, clean energy, water and waste management, food security, environmental quality, etc. To address these challenges, the recently adopted UN-Habitat New Urban Agenda (NUA) [2] has set a new standard for sustainable urban development "specially committed to:

- Provide basic services for all citizens;

- Ensure that all citizens have access to equal opportunities and face no discrimination;

- Promote measures that support cleaner cities;

- Strengthen resilience in cities to reduce the risk and the impact of disasters;

- Take action to address climate change by reducing their greenhouse gas emissions;

- Fully respect the rights of refugees, migrants and internally displaced persons regardless of their migration status;

- Improve connectivity and support innovative and green initiatives; 
- Promote safe, accessible and green public spaces".

Now national governments, as well as regional and local authorities, must take their turn in implementing the NUA and to that end, establishing the right technical and financial partnerships across the international community is of great importance. Likewise, national urban policies should be developed to support the implementation of the NUA by means of urban regulations, urban planning and design, and municipal finance. However, in practise, bridging the gap between national and regional policies and local intervention through concrete projects is far from being an easy task.

Ecocity projects can contribute to the achievement of the objectives of the NUA if used, not as rigid "models" of sustainable urbanization (much less as physical "models") to be replicated worldwide as intended by some of them [3,4], but as a transformative force and a laboratory for new ideas as argued by Rapoport [5]. Despite the constant challenge of finding a balance between utopian visions and concrete realizations [6], which has raised considerable criticism, ecocity projects can have a positive impact in terms of increasing environmental awareness, setting examples of good practice that might inspire new ecocity developments, testing innovative solutions, or sparking a public debate on what is a sustainable city. The benefits of demonstration projects is shown by the research on Northern European ecological communities conducted by Saunders [7].

More concretely, the EcoCity concept developed by VTT Technical Research Centre of Finland Ltd. (VTT) for sustainable community and neighbourhood regeneration and development has been designed to make possible the formulation of solutions that can be adapted to different local conditions supported by specific methodologies and effective facilitation processes and skills. As shown by Antuña-Rozado et al. [8], during the EcoMedellín project VTT's EcoCity facilitation enabled on the one hand the articulation of the "grey" and the "green" components, and on the other the change of scale by moving from national and regional policies to a specific local project [8]. Therefore, in this sense the EcoCity concept, methodologies and facilitation can help to bridge the gap identified in the implementation of the NUA. As it will be explained along the article, VTT's EcoCity concept is flexible and constantly evolving to allow the inclusion of other relevant perspectives like those introduced by digitalization (smart solutions), Nature-Based Solutions (NBS) or circular economy, if considered pertinent (and feasible) in the course of the dialogue established with local stakeholders. It seems necessary to clarify that "EcoCity" refers to VTT's own developed concept and related activities, whereas "ecocity" or "ecocities" refer to the generic concept, activities and examples.

Looking at the existing literature, there seems to be a general consensus on the fact that there is not a universally accepted definition of what is an ecocity, as pointed out by a number of authors like Roseland [9] or Joss [10]. This has led to a division in opinion between those that believe that the lack of a clear definition is detrimental to the validity of the concept, and those that consider it positive since it leaves enough margin for the development of locally attuned solutions in a variety of contexts worldwide like Surjan and Shaw [11] or Wong and Yuen [12]. The first ones often insist on the need for assessment frameworks and standards like the Ecocity Framework and Standards developed by Ecocity Builders \& the International Ecocity Advisory Committee [13], or indicators as proposed by Kline [14]. VTT's EcoCity concept probably lies somewhere in the middle of these two positions since as corroborated by the authors' experience, considerable flexibility is needed for local adaptation, but at the same time it is necessary to set targets and follow them up, as well as to monitor the performance in specific areas (e.g., air, energy, water).

There seems to be no consensus either regarding the scale of ecocity projects, which in practice can range from relatively small interventions (neighbourhood regeneration and urban retrofits) to whole new towns like those built in Asia and the Middle East. This diversity has led authors like Jabareen to define the ecocity as an "umbrella metaphor that encompasses a wide range of urban-ecological proposals that aim to achieve urban sustainability" [15], which matches quite well the authors' observations in all VTT's EcoCity related activities so far.

The in-depth critical analysis of concrete case studies carried out by some authors like e.g., Caprotti or Cugurullo, has contributed to expose the multi-faceted reality of ecocities and the challenges of the 
ecocity development process $[16,17]$, both relevant issues not sufficiently covered by the literature. It is for such process, particularly in its early stages that VTT's EcoCity concept provides a structured yet flexible framework for conducting the complex dialogue leading to ecocity implementation, which may be its main differentiating factor. Therefore, this article aims at contributing to the abovementioned debate on the complexities and nuances of the process towards the implementation of ecocities worldwide, as well as on the varying local conditions requiring adaptation. This contribution is half way between theory and practice, inasmuch as VTT's EcoCity concept is placed in the context of the ongoing ecocity debate, thus adding to its intellectual side, but the content and reflections provided originate from practical experience in guiding and supporting the multi-stakeholder dialogue, as the Libyan case study presented illustrates.

\section{Research Aim, Methodology and Novelty of the Approach}

VTT's EcoCity concept has been designed and improved through collaboration with local partners and stakeholders for the improvement of human settlements around the world, especially in the Global South. The aim of the research shown here is two-folded. On the one hand, to frame the theoretical and historical underpinnings of the concept in relation to the general ecocity debate, thus completing the trilogy including the two previous articles $[8,18]$ focusing on its practical side and covering the methodologies and facilitation processes and skills specifically developed to support the implementation of the concept. On the other hand, to exemplify through a case study how the concept is applied in practice in a specific local context

The methodology followed consists of first explaining why and how the concept developed by VTT emerged, and its links to the Finnish urban development tradition illustrated through relevant examples (Tapiola Garden City, Otaniemi High-Tech Park, and Eco-Viikki) and future opportunities provided by emerging concepts (e.g., Circular Economy and Nature-Based Solutions); then discussing its main components in relation to different approaches, proponents, scope, etc., within the general ecocity panorama; after that showing how the concept and its objectives are communicated and carried forward, briefly illustrated through a case study (Libya); and finally drawing conclusions from the experience in numerous EcoCity activities and projects worldwide.

In short, VTT's EcoCity concept relies upon: (1) the close collaboration with reliable local partners; (2) the adaptation of the solutions proposed to the local conditions; (3) the effective participation of key stakeholders; and (4) the use of specific methodologies and facilitation processes and skills mentioned above. The previous aspects when considered separately do not necessarily constitute a novelty, but their integration into a holistic and flexible framework certainly does. Seen retrospectively, the fact that such framework is used to guide and support the multi-stakeholder dialogue ultimately leading to ecocity implementation, invariably complex and full of challenges, particularly in the first stages, is particularly value-adding. In addition, experience corroborates the importance of adequate assessment tools and indicators in order to set targets and monitor their degree of achievement. Consequently, the concept is enriched and strengthened with each case study, and in turn, the concept thus improved benefits subsequent case studies, resulting in a sort of "continuous improvement feedback loop" which is another novel aspect.

\section{Background and Main References}

The ecocity concept presented was formulated in Finland, a Nordic country with a long history of promoting sustainable development, both nationally and internationally. The Finnish National Commission on Sustainable Development (FNCSD) was established in 1993, following the repercussion of the Brundtland Commission Report [19], and the 1992 Rio Conference with its subsequent Declaration on Environment and Development [20]. Since its inception the FNCSD has implemented numerous programmes and strategies, the latest of which, "The Finland we want 2050 - Society's Commitment to Sustainable Development" was adopted in 2013 and updated in 2016 in alignment with the UN 2030 Agenda for Sustainable Development [21]. The Finnish approach towards sustainable development is a 
holistic one, integrating "the wellbeing of people and the environment, a healthy and sustainable economy and the promotion of sustainable lifestyles" [22]. VTT's EcoCity concept stands on the same holistic approach while trying to respond to the needs and challenges typically associated to sustainable community and neighbourhood regeneration in the Global South. To achieve successful results in this regard, close collaboration with reliable local partners and relevant stakeholders has proved to be of crucial importance, as well as adaptation to varying local conditions as discussed by Antuña-Rozado et al. [8]. The references discussed in the next paragraphs should not be considered as a separate set of examples belonging to a specific domain, but as part of a much wider process spanning for decades and involving political commitment, constantly developed technical capacity, adequate legislative framework, and strong citizens' awareness and participation. It is rather this long-term societal quest for sustainable development that should be promoted, instead of a fragmented approach marked by a series of costly flagship ecocity projects, which very often fail in fulfilling the initial expectations. Particularly successful examples of sustainable urbanization in Europe like Freiburg (Germany) or Vitoria-Gasteiz (Spain) to name a couple, corroborate the importance of an integral approach sustained in the long run.

When focusing more specifically on Finland's urban planning and development tradition, the main references of VTT's EcoCity concept are Tapiola Garden City (1950s and 1960s, Espoo), Otaniemi High-Tech Park (1960s, Espoo) and Eco-Viikki (1990s, Helsinki). Based on Ebenezer Howard's Garden City (1898-1902) and its first practical applications in England (Letchworth, Hampstead Garden Suburb and Welwyn Garden City) [23], Tapiola Garden City in Espoo, a municipality next to Helsinki, was built by the Finnish Housing Foundation in response to the great post-war social demand for housing. The project responded mainly to the vision of Heikki von Hertzen, the executive director of the Housing Foundation at the time, who wanted to create "a modern city that would address the housing shortage in Helsinki and would be both economically viable and beautiful" [24]. His somehow utopian vision went beyond the dwellings and aimed at building a healthy city that would provide an alternative to what was perceived at the time as an "oppressive urban environment", in the form of a self-sufficient community providing all services and facilities necessary to meet the needs of 30,000 inhabitants including the surrounding districts [25].

The original plans for Tapiola Garden city made by Otto-Iivari Meurman were modified by the Housing Foundation and then handed over to a group of prominent Finnish architects like Alvar Aalto, Aarne Ervi and Kaija Siren who were commissioned to design their own part of the city and its buildings. Other innovative features of Tapiola Garden City, even more considering the period during which it was built, was the multi-disciplinary and participatory approach taken. The city was the result of a successful teamwork that involved architects, civil engineers, sociologists, landscape architects, and experts in domestic science and child welfare. Participation was considered at different stages of its development, and even the name of the city itself ("Tapiola" derives from Tapio, the Finnish forest god mentioned in Kalevala) was chosen through public competition [26]. An adequately validated participation of key stakeholders (see Antuña et al., [8]) is an essential component of VTT's EcoCity concept, which builds on the participatory tradition of Finnish urbanism exemplified by Tapiola Garden City.

The development of Otaniemi High-Tech Campus was initiated in 1946 when it was decided to move the Helsinki University of Technology (TKK, nowadays Aalto University) and the Technical Research Centre of Finland (VTT) from Helsinki city centre to Otaniemi in Espoo. Gradually, different facilities were built and by the beginning of the 70s, most departments of TKK had moved to the new location [27]. The heart of Otaniemi High-Tech Campus consists of the main university buildings like the auditorium, the library, administration offices, a number of faculties and a small shopping centre. Close by there is housing and other facilities such as a convention centre, a sports hall, a chapel and a hotel.

At present, Otaniemi is a technology and innovation hub that brings together academia, research and high-tech companies (also start-ups) in a very stimulating natural environment well accessed by public transport, including the recently inaugurated metro line between Helsinki and Espoo. Very soon 
Otaniemi will also host the European Space Agency's (ESA) new arctic space accelerator, and the first European United Nations Technology Innovation Lab (UNTIL) at the recently established A Grid start-up hub [28]. Like Tapiola Garden City and Otaniemi High-Tech Campus, VTT's EcoCity concept promotes an urban model where nature is strongly present, and within walking distance, in the form of forests and wild areas, historic mansion parks, other parks of various sizes, gardens, and lakes for all the citizens to enjoy its biodiversity and benefit from the ecosystem services provided.

Eco-Viikki has attracted a lot of attention both nationally and internationally since it was built in the 1990s, following an architectural competition that specified that proposals had to be ecologically sustainable through the minimization of the use of non-renewable energy sources and rapidly diminishing raw materials, reduction of pollution levels, noise and waste; minimization of the stress on natural resources and local ecosystems; residents empowerment and awareness raising on ecological sustainability [29]. Research programmes for Sustainable Development and Ecological Buildings were initiated to establish what sustainable development in urban planning and building entails. The need to test ecological principles in practice resulted in an invitation to local authorities around the country to work on experimental ecological construction in January 1994 [30]. Figure 1 shows a few images of the main references discussed.
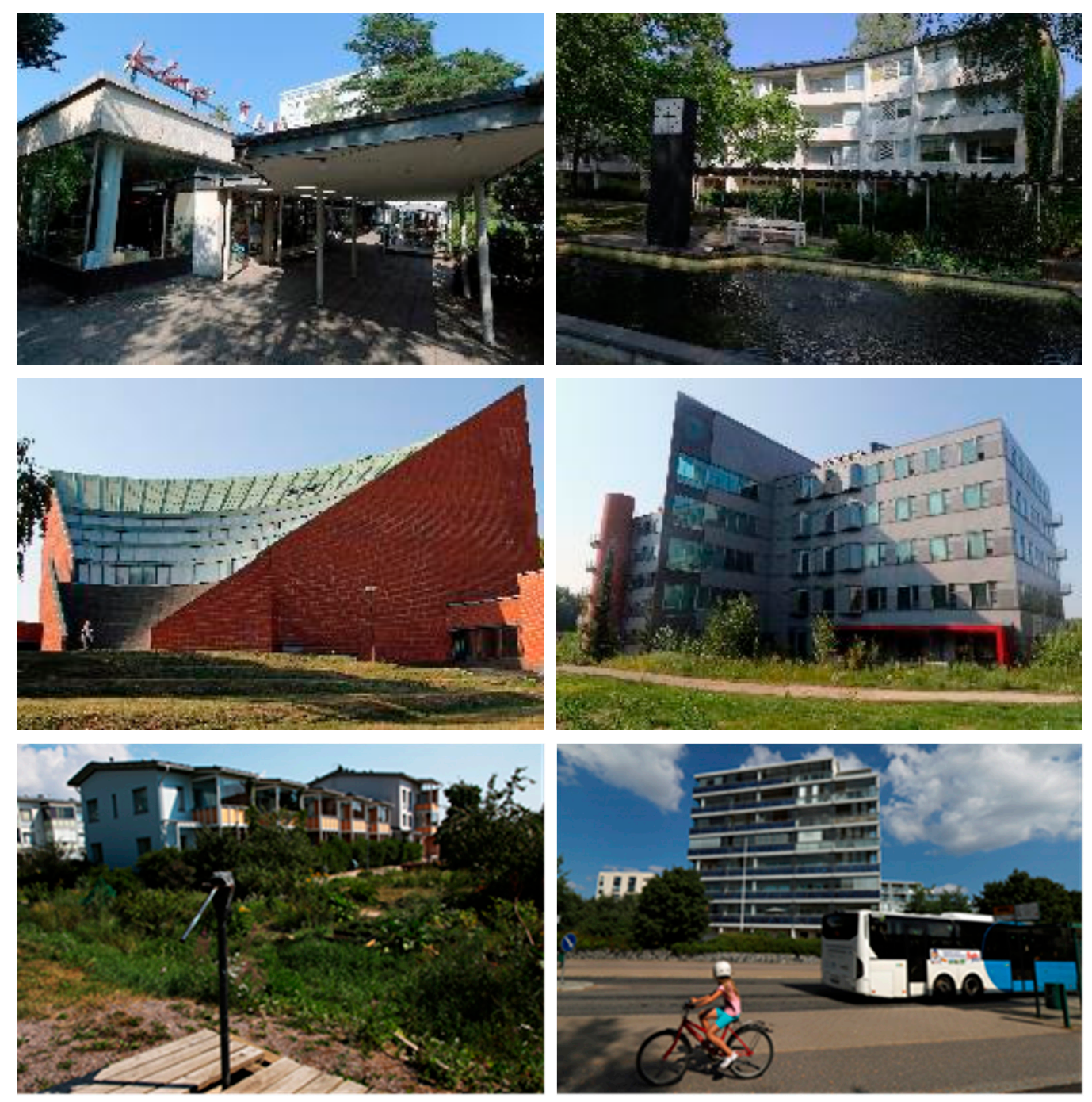

Figure 1. Top row: Tapiola Garden City, the first centre and housing developments from the 1950s. Middle row: Otaniemi High-Tech Campus, Undergraduate Centre (left) designed by Alvar Aalto and nowadays part of Aalto University, and Technopolis Innopoli 1 office park (right). Bottom row: Eco-Viikki. (All photos: Pekka Huovila). 
In Helsinki, Viikki was chosen as a test bed because it was sufficiently urban, connected to the existing communal structure and easily accessible by public transport. Already at an early stage, there was an awareness that ecological criteria were required to assess the ecological profile of the neighbourhood. Since no such measures were in use in Finland at the time and it was felt that various criteria used elsewhere could not be directly applied to Finnish conditions, a group of building consultants defined those specifically for Viikki in 1997. These criteria were used to assess the emissions, resource efficiency, human health, biodiversity and local food production of the projects to be developed [31]. This constitutes a clear example of adaptation to the local context, of the assessment framework in this case, which is a defining characteristic of the EcoCity concept discussed. The winning entry (of 91 proposals submitted) was based on a finger-like structure where the buildings are grouped around residential precincts ("home zones" where pedestrians have the right of way), with "green fingers" penetrating between the built areas, so that every plot is directly linked to the green areas. The major part of the buildings were directed optimally towards the south [29]. Figure 2 shows both the criteria established and the solutions adopted for Eco-Viikki.

\begin{tabular}{|c|c|c|c|c|}
\hline \multicolumn{5}{|c|}{ ECOLOGICAL CRITERIA FOR ECO-VIIKKI } \\
\hline POLLUTION & NATURAL RESOURCES & HEALTH & BIODIVERSITY & NUTRITION \\
\hline $\begin{array}{l}\text { Carbon dioxide emissions } \\
\text { Clean water consumption } \\
\text { Building material waste } \\
\text { Household waste } \\
\text { Environmental labelling }\end{array}$ & $\begin{array}{l}\text { Primary energy } \\
\text { Heating energy } \\
\text { Electrical energy } \\
\text { Adaptability and multi-use of } \\
\text { space }\end{array}$ & $\begin{array}{l}\text { Indoor climate } \\
\text { Moisture risks } \\
\text { Noise } \\
\text { Wind and sun } \\
\text { Alternative house plans }\end{array}$ & $\begin{array}{l}\text { Plant selection and habitat } \\
\text { types } \\
\text { Storm-water management }\end{array}$ & Cultivation of useful plants \\
\hline \multicolumn{5}{|c|}{ SOLUTIONS ADOPTED FOR ECO-VIIKKI } \\
\hline \multicolumn{2}{|c|}{ "GREEN FINGERS" extending into the block structure } & \multicolumn{3}{|c|}{ Provide opportunities for farming and composting, as well as for the utilization of rainwater collectors } \\
\hline \multicolumn{2}{|l|}{240 M2 OF SOLAR PANELS } & \multicolumn{3}{|c|}{$\begin{array}{l}\text { Provide electricity to } 39 \text { apartments. (Finland's first apartment building generating solar electricity was } \\
\text { built in Viikki in 2003) }\end{array}$} \\
\hline \multicolumn{2}{|c|}{ VARIOUS SOLAR SYSTEMS TESTED IN DIFFERENT ROOFS } & \multicolumn{3}{|c|}{$\begin{array}{l}\text { The thermal energy generated is utilized primarily in domestic water heating, and also for floor heating } \\
\text { in wet spaces }\end{array}$} \\
\hline \multicolumn{2}{|c|}{ RESIDENTS' BUILDING (2002) } & \multicolumn{3}{|c|}{ Common activity facility the cost of which is shared by all housing corporations } \\
\hline \multicolumn{2}{|l|}{ DENSE VEGETATION } & \multicolumn{3}{|c|}{$\begin{array}{l}\text { Planted to attenuate the windiness of the area, improve living comfort and reduce buildings' energy } \\
\text { consumption }\end{array}$} \\
\hline \multicolumn{2}{|l|}{ DITCH REPOSITIONED } & \multicolumn{3}{|c|}{$\begin{array}{l}\text { Formerly running through the green areas, now separates the housing and the large open recreational } \\
\text { area }\end{array}$} \\
\hline \multicolumn{2}{|c|}{ GOOD QUALITY ARCHITECTURE } & \multicolumn{3}{|c|}{ Combined with the use of renewable energy sources and local food production } \\
\hline \multicolumn{2}{|c|}{ VIIKKI ENVIRONMENT HOUSE (2011) } & \multicolumn{3}{|c|}{$\begin{array}{l}\text { Finland's most energy-efficient office building was built close to the Eko-Viikki area developed in } 1999 \text { - } \\
2004\end{array}$} \\
\hline
\end{tabular}

Figure 2. Ecological building criteria for Eco-Viikki and main solutions adopted. Own elaboration based on content in [29].

Beyond the initial ecological requirements, small-scale solar energy production and storm water management solutions, together with other sustainable technologies have been tested and monitored in Viikki. An extensive post-occupancy analysis identified the most successful applications from the residents' perspective. The findings indicated that, despite of real energy and water consumption levels being higher than projected, the strategies implemented still reduced those below standard development [32]. Developing an assessment framework that responds to the local conditions and following it up throughout the ecocity development process, as well as complementing it with monitoring of specific areas of performance (e.g., energy, water, etc.), is also encouraged when conducting a dialogue with stakeholders guided by VTT's EcoCity concept.

Although Eco-Viikki reflects its time, in the mid-1990s ecology was almost a synonym for sustainability, it managed to show how ecological sustainability goals can create not only ecologically-friendly, but also socially-mixed urban living environments with numerous options concerning their financing and forms of ownership. The solutions created originally from an ecological viewpoint gave the area a positive identity, increased residents' initiative and sense of community, added life to the shared yards, and increased the opportunities for inhabitants of all ages to spend time outdoors. 


\section{Sustainable Urban Development in Finland During Recent Years}

Many relevant initiatives in terms of sustainable urban (and regional) development and regeneration have followed Eco-Viikki, in not only Helsinki, but also all across the country. An exhaustive description of those would make this article too long; therefore, what follows is rather an overview of where the process has led focusing on its present highlights. From a wider perspective and with regards to sustainable development, current initiatives in Finland are to be framed within the most important international agreements (already mentioned), and European strategic documents like the White Paper on the Future of Europe [33] or the recently published Towards a Sustainable Europe 2030 [34].

To its long tradition in supporting sustainable development, Finland can also add the accomplishment of having developed the world's first road map to a circular economy, "Leading the cycle-Finnish road map to a circular economy 2016-2025" [35]. Led by the Finnish Innovation Fund, SITRA, the road map outlines the steps towards sustainable success through "pioneering solutions to ensure that economic growth and increased well-being are no longer based on the wasteful use of natural resources". With an emphasis on concrete practical actions that can help to accelerate the transition to a circular economy, the road map gathers a collection of best practices and pilots involving all kinds of stakeholders (ministries, regions, cities and municipalities, companies, universities, research organizations, etc.). The focus areas for these actions are Sustainable food system, Forest-based loops, Technical loops, Transports and logistics, and Common actions.

Among the Finnish cities and municipalities committed to the development of innovative circular economy solutions (Ii, Jyväskylä, Kuopio, Lahti, Lappeenranta, Porvoo, Riihimäki, Rovaniemi, Turku and Vantaa), the city of Lahti constitutes a leading example of integrated waste management, not only in households, but also at an industrial level. If everything goes as planned, incineration and landfilling of waste in Lahti will stop by 2050. Moreover, the Päijät-Häme region, to which Lahti belongs, published in 2017 the first regional road map for circular economy. This environment is attracting all kinds of Cleantech companies.

In addition to circular economy, some Finnish cities and municipalities are also pioneering the development and implementation of Nature-Based Solutions (NBS) in response to climate change derived challenges. As an interesting example, Tampere, the third largest city in Finland, is investing in innovative co-created NBS for storm water management and the prevention of flooding since, according to the latest projections, rainfall in Finland will increase significantly in the coming years due to climate change [36]. Other challenges are air and water pollution, and reduced biodiversity. Tampere's main NBS demonstration site is Vuores, a green district to be completed by 2030, providing residence for 13,000 people and 3000 to 5000 jobs (see Figure 3). The NBS demonstrated in Vuores will be scaled up and further developed in Hiedanranta, a former industrial area to be transformed into a residential area for 25,000 inhabitants and more than 10,000 jobs.

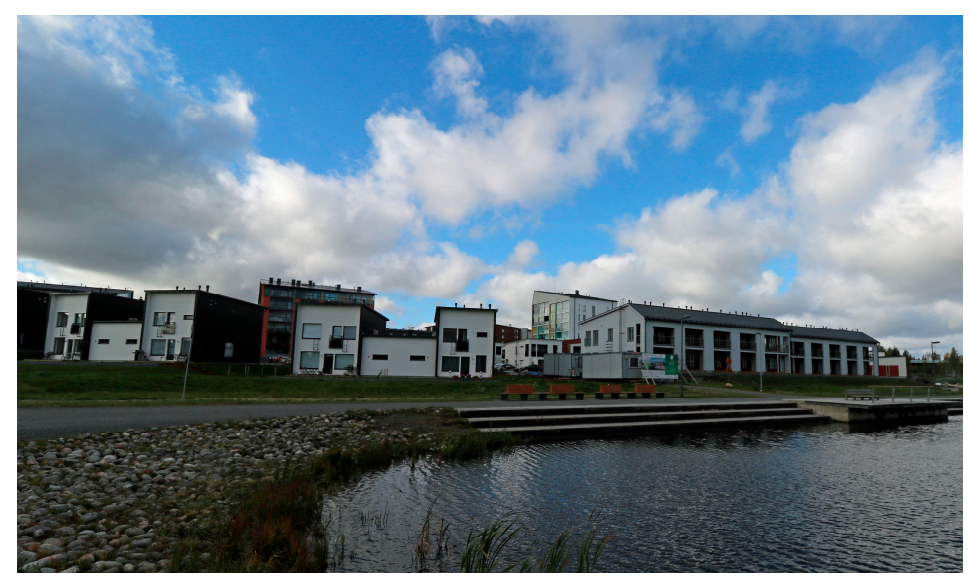

Figure 3. View of the storm water retention pond in Vuores Central Park. (Photo: Pekka Huovila). 
In the authors' view, there seems to be potential for "cross-fertilization" between circular economy and NBS, and eco-urbanism. However, since these can be still considered emerging concepts, there are not many examples of such hybridization.

\section{Approach towards Sustainable Community and Neighbourhood Regeneration and Development}

In this Section, the theoretical support of VTT's EcoCity concept is presented in relation to different approaches, proponents, etc., and in reference to concrete EcoCity activities and projects for better understanding. From the early days of ecocities as envisioned by Richard Register-mainly focusing on ecological aspects; through broader definitions of the term including also economic and socio-cultural aspects, or even localized visions like those proposed in Asia; to the more recent critical evaluation of notorious flagship projects worldwide.

\subsection{Beyond the Strictly Ecological}

Richard Register coined the term "ecocity" in 1987, when the concept of sustainability also emerged [37]. Back then, ecology and sustainability were considered almost the same, as it has been already pointed out when discussing Eco-Viikki. Along with time, other proponents and practitioners have expanded Register's definition of an ecocity as an "ecologically healthy city" to include, in recent years, issues like resilience and climate change as discussed by Newman et al. [38]. Likewise, VTT's EcoCity concept goes also beyond the strictly ecological in favour of a more general approach covering also economic, social and cultural aspects, quite close to Maclaren's vision of "inter-generational equity, intra-generational equity, protection of the natural environment, minimal use of non-renewable resources, economic vitality and diversity, community self-reliance, individual wellbeing, and satisfaction of basic human needs" [39]. Furthermore, it also goes beyond the narrow focus on GHG emission reduction that dominated ecocity development in the period that followed the adoption of the Kyoto Protocol in 1997, in the implementation of which cities played an important role.

\subsection{Local Definition (Negotiated and Agreed) of Sustainability}

Experience from a number of EcoCity projects and activities worldwide corroborates the importance of adaptation to the local context due to varying socio-economic, socio-political, socio-ecological and cultural conditions as explained by Antuña-Rozado et al. [8] and illustrated through EcoMedellín and EcoLusaka case studies [8]. Supporting communities to develop and implement their own definition of sustainability is essential to the purpose, very much in line with Roseland [9] for whom there is not one universal definition of the ecocity and perhaps there should not be. Instead, he suggests establishing certain necessary conditions. Similarly, VTT's facilitation for EcoCity development tries to ensure that the framework defined together with local partners and stakeholders stays within the boundaries of the non-negotiable (necessary) conditions previously discussed and agreed upon, while allowing flexibility for locally attuned solutions to emerge.

Furthermore, authors like Wong believe that the particular idiosyncrasy of Chinese cities, as an example, justifies the implementation of their own form of sustainability focusing on a series of priority measures, which may not coincide with those of Western countries where some of them are commonly in use since decades [40]. In a similar manner, history and tradition may offer not only inspiration, but also a solid ground for local adaptation. For instance, in relation to modern Japanese cities, Brown suggests to take a look at the past, particularly that of the Edo period, just before industrialization, when the Japanese lived in harmony with their environment, to see what lessons can be drawn that may help us to achieve sustainability today [41].

\subsection{The Role of Technology}

Being born in Finland, one of the most technologically advanced countries in the world, technology certainly plays a central role in VTT's EcoCity concept, which is very common in contemporary ecocity initiatives around the world as shown by Joss [42]. Masdar City in Abu Dhabi (initiated in 2006) is a 
very well-known example of ecocity featuring a number of clean technologies for the minimization of energy and water consumption, use of renewable energies, waste reduction, water and waste treatment, sustainable and smart transportation, etc. [43]. However, experience from EcoCity projects and activities shows that, as important as it may be, technology alone is not enough to address the complexity of the challenges faced by cities in their transition to sustainability. This is corroborated by a number of authors when critically analysing the results of major ecocity projects with a particular emphasis on technological aspects in China, Japan or South Korea, as an example. In China, the unified top-down approach to ecocity planning and implementation fostered by the central government has failed to take into account the specific local conditions (including local culture and narratives) and to engage the community in a meaningful way along the process [44]. According to Low, Japanese ecocities reflect the tension between tradition and modernity with a strong focus on the revitalization of urban centres by shifting to green technologies and renewable energy sources [45]. Similar in many ways to their Chinese counterparts, ecocity projects in South Korea put an even bigger emphasis on information and communication technology and smart solutions [46]. Songdo, an ambitious "u-eco-city" (ubiquitous-eco-city, a South Korean invention) already in its second phase of development, is an example of some of the intrinsic contradictions shared by many of these technology reliant ecocity projects. Located on the waterfront of Incheon city, its developers have sought to introduce a wide array of sustainable building practices, energy-efficiency measures, construction waste recycling, etc. However, Songdo is a large reclamation project built on former tidal-flats and sea-shallows causing an important loss of valuable biodiversity, e.g., shorebirds and water birds [47].

\subsection{No Reliance on Physical Planning}

Authors like Sharifi [48] or Holden and Li [49] maintain that, like the preceding urban planning movements, eco-urbanism relies too much on physical design to create social change, often ignoring important drivers and processes (see social aspects ahead) and thus compromising the success of the implementation. In this sense, VTT's EcoCities rather support a performance-based instead of a prescription-based approach to ecocity planning and development, very much in line with the idea of pluralism proposed by Bond et al. as an alternative to physical determinism [50]. The result is a flexible framework that can be applied at different scales, allows the participation of all relevant stakeholders, and takes into consideration the local context. Moreover, participation and capacity building are at the core of VTT's EcoCity concept as explained in previous articles and illustrated here by the Libyan case study. However, to guarantee the validity and governance of the results, certain requirements must be fulfilled in relation to the participants and the process [8]. Additionally, whereas certain local conditions are favourable to bottom-up initiatives and enable active and meaningful participation, others lead almost invariably to the adoption of a top-down approach and deficient stakeholder participation as already mentioned above in the case of Chinese ecocities.

\subsection{Emphasis on Social Aspects}

As discussed in the previous two articles, the experience and knowledge gained through a number of projects inside and outside Europe were the basis for the formulation of VTT's EcoCity concept. One of those early examples before the concept was formalized was a feasibility study to analyse the possibilities for an EcoCity to be built in Miaofeng Mountain Town in Mentougou District (Beijing, China). The area has high ecological value, which presents some restrictions, and consists of 17 separate villages. The study provided recommendations for the development of a long-term EcoCity model that would, not only address the existing environmental challenges, but also suggest activities (e.g., agriculture, tourism) to improve the economic performance of the whole area, and enhance the local culture and way of life. In addition, a set of guidelines were also developed covering the following categories: natural environment; built environment; urban structure, land demand; land uses, mixed used; public space; landscape and green areas; urban comfort; buildings; transport modes and public transport; individual motorized traffic; transport of goods; energy, water and waste 
flows; building materials; socio-economy, social issues; economy; costs. A Sustainable Community Rating System based on indicators (environmental, economic and social) and specially developed for Miaofeng Mountain Town, complemented these guidelines [51].

In contrast with the recurring criticism of eco-urbanism worldwide generally showing an "asymmetrical implementation of the three dimensions of sustainability", or even using the environmental and social aspects to mask the real economic concerns driving ecocity projects as maintained by Cugurullo [52], VTT's EcoCity concept tries to balance all dimensions of sustainability through a holistic approach paying particular attention to issues of social and cultural importance. Especially concerning social and cultural issues, it is important to mention that a good number of VTT's EcoCity projects were either funded or somehow supported by the Ministry for Foreign Affairs of Finland. Consequently and to the extent that the nature of each of the projects allowed, they were aligned from the onset with Finland's Development Policy, which guides all those "activities aiming at reducing poverty, implementing fundamental rights and promoting sustainable development globally" [53]. Again, Nordic values are very much influencing the Finnish Development Policy, which currently focuses on four priority areas: (1) The rights and status of women and girls; (2) The growth of developing countries' economies to generate more jobs, livelihoods and well-being; (3) Democratic and better-functioning societies; and (4) Food security, access to water and energy, and sustainable use of natural resources [54].

\subsection{Importance of Considering User Behaviour and Promoting Sustainable Lifestyles}

Project experience shows that in order to achieve long-lasting results and to maximize the impact, it is important to engage the users. For example, as part of a Procurement Handbook for Sustainable Buildings commissioned by the United Nations in 2009, VTT worked on a case study in Kenya provided by the United Nations Environment Programme (formerly UNEP, now UN Environment). UN Gigiri, the new office facility in Nairobi housing the headquarters of both UN Environment and the United Nations Human Settlements Programme (UN-Habitat) aimed at being an environmentally sustainable showcase building for Africa [55]. When considering the possible measures that could be applied to decrease the building's energy consumption, it turned out that changing some of the users' behaviour had a considerable impact. The employees were used to have their own electric coffee makers and individual printers, even compact refrigerators in some cases. Coffee makers and refrigerators were removed and a space was arranged for a common cafeteria where the employees could enjoy their breaks together. Individual printers were replaced by a centralized copy room with multi-function printers. In general, all office equipment was changed to "greener" alternatives.

In all VTT's EcoCity projects and activities, the local partners and stakeholders acknowledged the importance of sustainable lifestyles either implicitly or explicitly. Most workshops, seminars, discussions, etc., highlighted the need to promote sustainable living and its connection with citizens' wellbeing and quality of life in cities. Hence, the efforts dedicated to awareness raising, capacity building and education, or citizens' participation as means to bring about social change if lasting results are to be achieved. Authors like Yu have pointed out that without true community engagement, eco-cities are not much more than a series of green and low carbon technologies often not fully understood by the ordinary residents [56]. Chinese eco-cities, typically developed without real involvement of the different stakeholders, usually miss out the valuable contribution that citizens can provide in terms of energy and resource savings, care for the environment, healthy living, social equality and inclusion. Once again, in the case of the Sino-Singapore Tianjin Eco-City, Flynn et al. have observed that not consulting the citizens about their lifestyles to know whether they are actually using the infrastructures available in the correct way may lead to malfunction or infra-utilization [57].

\section{A Libyan Case Study}

This section aims at illustrating through a case study how VTT's EcoCity concept is applied in practice to specific contexts worldwide, in collaboration with local partners and with the participation of relevant stakeholders. 
In June 2012, the Ministry of Housing and Utilities of Libya (MHU) conducted a study trip to Finland to gather knowledge on Finnish expertise, solutions and technologies for the sustainable built environment. The trip included a number of site visits and meetings with relevant Finnish actors (including VTT), and ended with the drafting of a "Road Map on Finnish-Libyan cooperation in the field of Housing and Utilities" by the Unit for Northern Africa of the Ministry for Foreign Affairs of Finland. The Road Map stated that "as a follow up, a feasibility study of Libyan ecocities could be made in collaboration with local partners, focusing on aspects of highest priority, e.g., drinking water, wastewater management, housing, etc." This resulted in a Fact Finding Mission to Libya carried out by VTT in June 2013 and organized by MHU with the overall objective of supporting sustainable community regeneration and development in the country covering a number of aspects like urban planning, water supply, waste management, affordable housing and capacity building on these issues. VTT's EcoCity concept was used as the framework for the definition of the process' phases: Phase I-Fact Finding Mission to understand better local priorities and resources and to prepare the next phase; Phase II-Feasibility Study for development and capacity building for the local stakeholders; and Phase III-Implementation. However, despite the plans for continuation and the efforts made together with the local partners to cover also Phases II and II, due to the circumstances only Phase I illustrated here could be completed. In this context, Phase I-Fact Finding Mission to Libya consisted of the following tasks:

- Understanding local priorities through site visits and meetings with the authorities and other key stakeholders.

- Discussing the components of VTT's EcoCity concept with local decision makers.

- Meeting local business actors and academia to know better local market features, current practices and constraints, and to facilitate access to information.

- Identifying potential funding instruments or bodies that might support the development and implementation of EcoCities in Libya.

Table 1 summarizes the activities arranged during the Mission and the priority topics discussed, whereas Figure 4 shows the challenges, opportunities and risks identified during those discussions for EcoCity development in Libya. However, even though Libyan stakeholders were quite well represented and the agenda was very efficiently organized considering the relatively short time available, unfortunately civil society organizations (CSOs) and citizens associations were not engaged in those activities. This could have been solved in the subsequent phases, but as abovementioned, Phases II and III were never undertaken.

From the meetings with the different Libyan authorities and stakeholders it became clear that all the components defined for VTT's EcoCity concept, namely Energy Efficiency, Food Security, Jobs \& Services, Public Transport, Sustainable Housing, Waste Management, and Water Security as shown by Antuña et al. [3], were very relevant in the Libyan context. Regarding the prioritization of those components, it also became evident that the emphasis should be on addressing the housing shortage in the country (around 400,000 housing units needed to be built in the coming years) while providing solutions for the serious environmental threats derived from the deficient management of wastewater and solid waste. 
Table 1. Summary of meetings and site visits carried out during the Fact Finding Mission. (Carmen Antuña-Rozado, 2018).

\begin{tabular}{|c|c|c|c|}
\hline Location & Organizations/Stakeholders & Priority Topics & Site Visits \\
\hline Tripoli & $\begin{array}{l}\text { Ministry of Housing and } \\
\text { Utilities } \\
\text { Tripoli Local Council } \\
\text { Urban Planning Agency (UPA) } \\
\text { Libyan National Centre for } \\
\text { Standardization and } \\
\text { Metrology (LNCSM) } \\
\text { Housing and Infrastructure } \\
\text { Board (HIB) } \\
\text { General Company for Water } \\
\text { and Wastewater (GCWW) } \\
\text { General Company for } \\
\text { Electricity and Renewable } \\
\text { Energies } \\
\text { Ministry of Transportation } \\
\text { Ministry of Labour }\end{array}$ & $\begin{array}{l}\text { - } \quad \text { Briefing for the Mission and programme for } \\
\text { the week } \\
\text { - How does the market work, PPPs, leading actors, } \\
\text { incentives for sustainable building } \\
\text { - Tripoli Master Plan, environmental concerns, } \\
\text { waste management challenges } \\
\text { - Urban planning and land use in Libya, land } \\
\text { ownership, town planning procedures } \\
\text { - Standardization and certification, building } \\
\text { product approval, Building Code } \\
\text { Building typologies, density, household size and } \\
\text { social structure statistics, revenue } \\
\text { collection, sanitation } \\
\text { - Current state, objectives and solutions concerning } \\
\text { wastewater treatment and drinking } \\
\text { water management } \\
\text { Energy plans and tariffs, use of renewable sources } \\
\text { - Public transport system, road network, use of } \\
\text { private cars } \\
\text { Skills and willingness for job creation around } \\
\text { sustainable city development, training courses }\end{array}$ & $\begin{array}{l}\text { Old Town } \\
\text { Wastewater outlet } \\
\text { New housing } \\
\text { developments } \\
\text { Dumping site }\end{array}$ \\
\hline $\begin{array}{l}\text { Green } \\
\text { Mountains }\end{array}$ & Shahat Local Council & $\begin{array}{l}\text { - } \quad \text { The Shahat Declaration } \\
\text { - } \quad \text { Developing the tourism industry } \\
\text { - } \quad \text { Wassing plans } \\
\quad \text { waste collection }\end{array}$ & $\begin{array}{l}\text { Visit to the Green } \\
\text { Mountains region } \\
\text { Ancient Cyrene } \\
\text { archaeological } \\
\text { site } \\
\text { Susa }\end{array}$ \\
\hline Benghazi & $\begin{array}{l}\text { Benghazi Local Council } \\
\text { Libyan Green Building } \\
\text { Council (LGBC) }\end{array}$ & $\begin{array}{l}\text { - Benghazi Master Plan, environmental concerns, } \\
\text { waste management challenges } \\
\text { - Sustainable building and neighbourhood } \\
\text { assessment approach, certification plans }\end{array}$ & \\
\hline
\end{tabular}

\begin{tabular}{|c|c|}
\hline ECOCITY CHALL & OPPORTUNITIES \\
\hline $\begin{array}{l}\text { Legal framework } \\
\text { - No Building Code } \\
\text { - Subsidized pricing (no incentives for saving energy and } \\
\text { water) } \\
\text { - Illegal housing } \\
\text { - Lack of governmental commitment and enforcement } \\
\text { Environmental threats } \\
\text { - Untreated wastewater is already an environmental } \\
\text { catastrophe } \\
\text { - Solid waste management is also a priority issue } \\
\text { Housing } \\
\text { - Urgent need of housing } \\
\text { - Poor quality of existing built stock } \\
\text { - Lack of sustainable examples }\end{array}$ & $\begin{array}{l}\text { - Right time for Libyan EcoCity implementation } \\
\text { - Citizen's willingness for a sustainable built } \\
\text { environment } \\
\text { - } \begin{array}{l}\text { Activate existing contracts (currently paralyzed) } \\
\text { regarding wastewater treatment and housing }\end{array} \\
\text { - Awareness raising for water saving, waste } \\
\text { management, energy use, etc. } \\
\text { - Business from waste (calls for entrepreneurship) } \\
\text { - Tourism (requires improved quality and service } \\
\text { attitude) } \\
\text { - Readiness of Ministry of Electricity and Renewable } \\
\text { Energy for wider exploitation of renewable energy } \\
\text { sources, e.g. solar domestic water heating } \\
\text { - Readiness of Ministry of Labour for training job } \\
\text { seekers and unqualified people for sustainable } \\
\text { construction }\end{array}$ \\
\hline
\end{tabular}

Figure 4. Challenges and opportunities for EcoCity development in Libya. (Carmen Antuña-Rozado, 2018).

\subsection{EcoCity Action Plan for Libya}

Based on the understanding of the Libyan context and needs obtained from the abovementioned discussions and targeted visits, an EcoCity Action Plan was proposed to be discussed with and validated by MHU (see Figure 5) including three main components: 


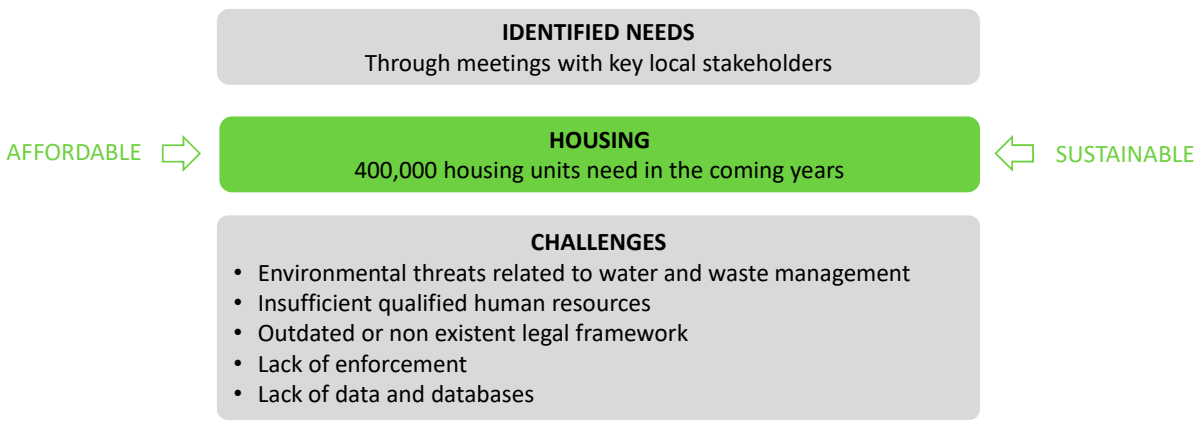

ECOCITY ACTION PLAN FOR LIBYA: MAIN COMPONENTS

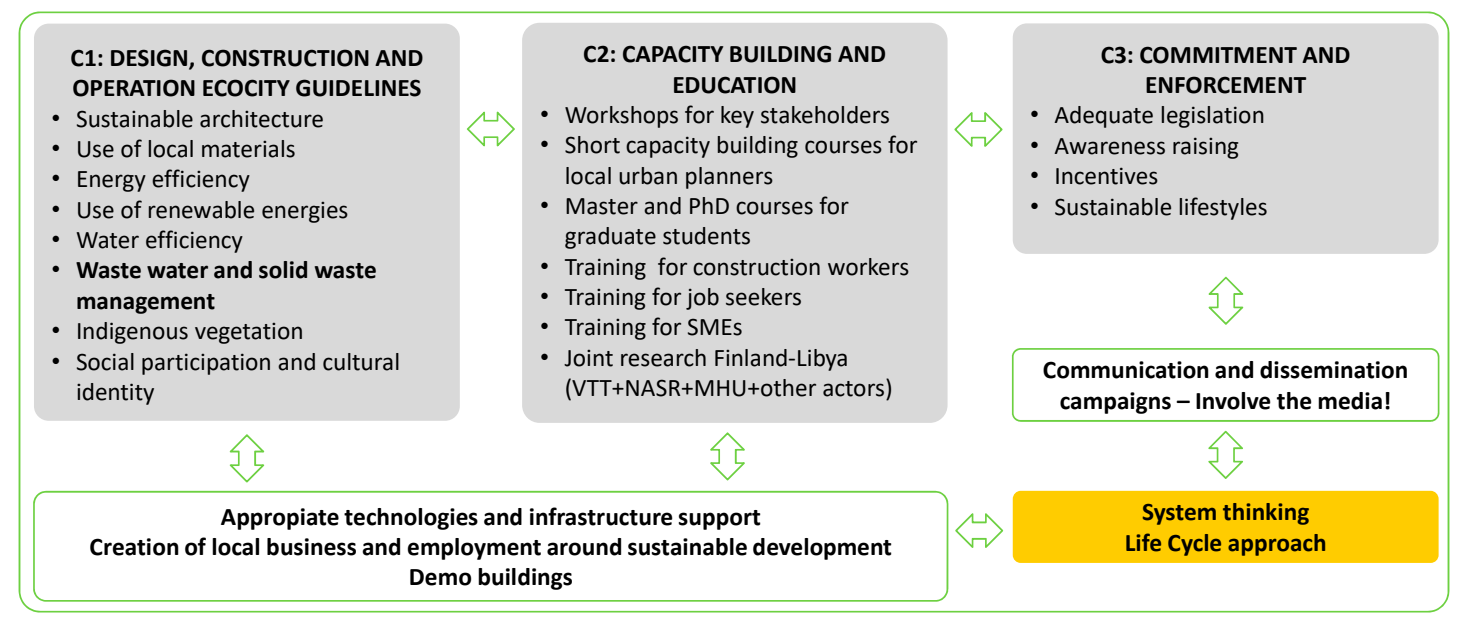

Figure 5. EcoCity Action Plan for Libya. (Ministry of Housing and Utilities of Libya, VTT Technical Research Centre of Finland Ltd.).

- EcoCity Guidelines for the design, construction, operation and maintenance of buildings (C1)

This component responded to the urgent need of housing and the will of the Libyan authorities to make it sustainable and to initiate a transformation towards the implementation of the EcoCity concept in Libya. In this context, the direct application and demonstration of the EcoCity principles in the Libyan environment through selected pilot projects was deemed essential.

The list included in Figure 5 (Sustainable architecture; Use of local materials; Energy efficiency; Use of renewable energies; Water efficiency; Wastewater and solid waste management; Indigenous vegetation; Social participation and cultural identity) is not comprehensive, but it gives an idea of the principles that can be explored through the pilot projects. Addressing the problem of wastewater and solid waste management is of the utmost importance given the magnitude of the associated environmental (and social) impacts: pollution of the Mediterranean Sea, lagoons and groundwater; health and sanitation threats for the population, etc.

On the other hand, in the absence of proper building regulations and building code, the EcoCity Guidelines could serve as the first draft for the future Building Code for Libya, and as a blueprint for the Libyan administration to aid the design, construction and operation of all public buildings, including public housing. Citizens' participation is necessary to overcome initial opposition to the implementation of EcoCity principles and fundamental if long-term results are to be achieved.

\section{- $\quad$ Capacity Building and Education (C2)}

To carry out the previous component successfully, it is necessary to build the capacity of all the stakeholders involved through training and education programmes, hence the activities listed in Figure 5. Components $\mathrm{C} 1$ and $\mathrm{C} 2$ should be supported by the implementation of appropriate 
technologies customized to suit the Libyan context avoiding a direct application of ready-made solutions that most likely will not work in the local environment.

All along the project, the creation of local businesses and employment around sustainable development should be promoted in order to strengthen the economic tissue of the country and contribute to its growth. This explains the stress on training also Libyan SMEs (Small and Medium Enterprises). To complement this activity, a business incubator could be also considered.

Finally, the construction (or renovation) of a few number of "demo buildings" around the country, in parallel to the real pilot projects, might help to exemplify the EcoCity principles and serve for instance as information points.

\section{- Commitment and Enforcement (C3)}

This important component relies heavily on the shoulders of the Libyan authorities because it requires high political commitment extended to all Libyan institutions in order to succeed in the implementation of an EcoCity Action Plan for Libya. Likewise, more enforcement is needed to ensure its application. However, this enforcement has to be supported by the development of adequate legislation, and by the raised awareness of the citizenship through education towards more sustainable lifestyles and incentives for the implementation of such sustainability measures.

Developing a dissemination and communication campaign and getting the media involved might be a good way to reach a wider audience throughout the country.

Finally, the whole EcoCity Action Plan should be considered from a lifecycle approach (taking into account the whole cycle of materials and processes) and a system thinking perspective (understanding that most often the problems are interrelated and holistic solutions are needed).

\subsection{Potential EcoCity Pilot Projects in Libya}

Libyan authorities were committed to the sustainable reconstruction and development of the country and to the application of EcoCity principles to new urban developments as well as to the deteriorated areas existing in most Libyan cities. It is widely accepted that good urban planning and design contributes to citizens' wellbeing as argued by authors like Leyden et al. [58], and fosters economic growth by enabling new business opportunities and even attracting tourism as posited by Shoval [59].

The main components included in the Action Plan would be developed through real pilot projects in Tripoli, Benghazi and Shahat/Susa (Figure 6). The proposed projects dealt both with urban development (new housing) and with urban regeneration (refurbishment of existing neighbourhoods), and included different building typologies.

Unfortunately, due to the worsening of the socio-political conditions in Libya (see risk in Figure 4) shortly after Phase I was completed, it was not possible to continue towards Phase II (Feasibility Study) and Phase III (Implementation) and the whole process was left in stand-by to be resumed when the country's situation allows. 


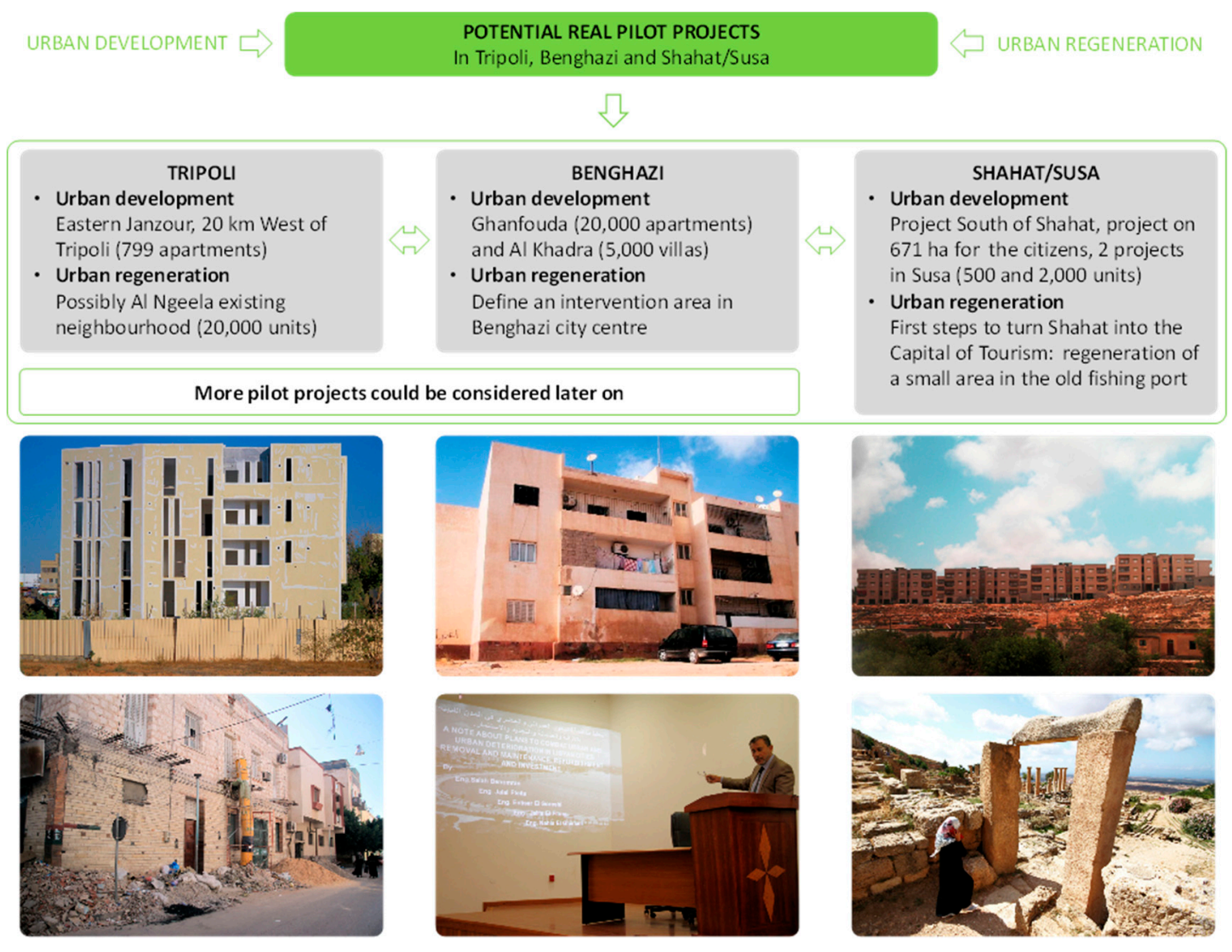

Figure 6. Potential Libyan EcoCity pilot projects in Tripoli, Benghazi and Shahat/Susa. (Ministry of Housing and Utilities of Libya, VTT Technical Research Centre of Finland Ltd. Photos: Pekka Huovila, 2013).

\section{Conclusions}

When reflecting on the purpose and the content of VTT's EcoCity concept in order to establish more clearly its theoretical and historical underpinnings, it becomes apparent that the concept builds on the Finnish tradition of urban planning and development, of which Tapiola Garden City, Otaniemi High-Tech Campus and Eco-Viikki are remarkable examples, as well as pioneering in many ways. For instance, the multi-disciplinary approach and strong emphasis on participation that characterize VTT's EcoCity concept were already present in the development of Tapiola Garden City as seen in Section 3, which at the time was rather a novelty. Many innovative solutions were successfully implemented in Eco-Viikki, even an ahead of its time introduction of NBS in the form of "green fingers" between blocks that enabled farming and composting, as well as rainwater collection. Another key component of VTT's EcoCity concept, adaptation to the local context, typically pursued in close collaboration with local partners and stakeholders, was also of particular importance when selecting the ecological building criteria for Eco-Viikki so that they would be suitable for the Finnish conditions.

Considered from an even wider perspective, Finland's long-standing commitment to sustainable development is defined by a holistic approach that aims at "a prosperous Finland with global responsibility for sustainability and the carrying capacity of nature" [22], and that also permeates VTT's EcoCity concept. However, such supportive environment, although mostly favourable for the formulation of this type of concept, entails the risk of taking for granted certain pre-conditions that pose a great concern for the target countries. In this sense, collaboration with local partners and stakeholders has been instrumental to make explicit what were originally implicit assumptions deriving from the Nordic view on sustainable development. This can be said of the ecocity concept in general. As Lye \& Chen point out, the ecocity concept has originated in North America and has developed largely based on urban practices carried out in North American, European and Australian cities, which may limit its 
applicability in other regions [60]. Moreover, as Myllylä and Kuvaja argue, the ecocity concept builds on the "societal structures and relations already in existence (namely, democracy, strong civil society participation, political accountability, etc.) in modern and post-modern societies", and consequently it may not be able to provide adequate solutions for the challenges faced by cities in the Global South, which very often lack the pre-existing structures required [61]. For the authors of this article this is certainly an issue not to be taken lightly, but it does not invalidate the applicability of the concept in "Southern" cities. Hence the flexible and interactive framework capable of accommodating different local interpretations of an ecocity, while respecting a series of key principles that cannot be compromised.

The importance of adaptation to the local context, for which specific methodologies have been developed, has been repeatedly stressed by Antuña-Rozado et al. [18]. But equally important is the consensual approach towards a negotiated and agreed local definition of sustainability, and therefore an "own" definition of an EcoCity that, respecting certain non-negotiable conditions, will be ultimately appropriated by the local community as a whole. Hence the relevance of expert facilitation to support the local actors along this complex decision-making process, to help them ground their decisions on the available scientific evidence, and to link the solutions jointly formulated to existing technologies. Moreover, regardless of whether any given EcoCity project is initiated and developed top-down or bottom-up, what really matters is rather ensuring that all key stakeholders are involved through real and meaningful participation.

Somehow it can be argued that the EcoCity concept discussed here combines framework, methodologies and facilitation to support stakeholders in the Global South in the development of locally attuned EcoCity solutions following a jointly defined EcoCity vision. However, experience shows that it ultimately generates capacities and adaptation, not only on the local side but also in relation to the concept itself and its facilitators, through a dynamic of mutual learning and continuous improvement. Hopefully, this approach can help to move away from the "labelling fever" and an overreliance on technology that, according to many critical voices, affects numerous flagship ecocity projects worldwide which unfortunately have failed in engaging the community and even in creating a true sense of place as discussed by Piew \& Neo [62]. Although it can be considered that the ultimate goal is the realization of an ecocity project, or in other words, a "built" ecocity, in the authors' view it is necessary to stress the complexity of the process leading to that realization, which very often does not receive the attention it deserves. VTT's EcoCity concept tries to contribute precisely to the dialogue that should be conducted as part of that process, and that as such has a value in itself, which should be separated from the final outcome-the built ecocity. Table 2 summarizes the results of the comparison between VTT's EcoCity concept and different approaches, which was explained more in detail in Section 4.

Table 2. Comparison between VTT's EcoCities and other approaches (Carmen Antuña-Rozado, 2018).

\begin{tabular}{cc}
\hline Other Approaches & VTT's EcoCity Approach \\
\hline Ecologically centered & Integrated \\
\hline Rigid models to be replicated worldwide & Locally defined \\
\hline Technodels limited by non-negotiable principles \\
\hline Prescription based (physical design) & Technology “conscious" \\
\hline Disregard for social aspects & Performance based \\
\hline Lack of users/community engagement & Emphasis on social aspects \\
\hline
\end{tabular}

The Libyan case study illustrates how this dialogue is conducted. The EcoCity Action Plan for Libya drafted in collaboration with the local stakeholders attempts to build a bridge between the general vision posited by the "Road Map on Finnish-Libyan cooperation in the field of Housing and Utilities" (see Section 5) and the formulation of specific projects in selected intervention areas by supporting and informing what is always a complex decision-making process. When compared with 
the Medellín case study, it can be seen how the same EcoCity concept leads to a different "Action Plan" precisely due to its flexibility, which enables adaptation to varying local contexts. The pilots identified in both cases are an important aspect in this transition towards concrete intervention projects because they connect the concept (theory) with the real examples (practice). However, the highly volatile situation in Libya, and in many other countries of the Global South for that matter, constitutes a serious hindrance for the full implemention of an ecocity transformation process, which is by nature complex and takes rather a long time to realize. The "global north-based urban knowledge production system" as Nagendra et al. rightfully call it [63], is supported by consolidated democracies, strong civil society participation (and awareness) and political accountability. The conditions in the Global South are very different from those that have shaped the urban development in the Global North, and therefore a new approach is required that potentiates the local capacities and pays attention to the specificities of the context. In the same paper, Nagendra et al. argue that despite the numerous challenges, cities in the Global South offer many opportunities for sustainability and have unique innovation and experimentation potential. Even though unfinished, the EcoCity path initiated in Libya may be a valid example of how to "downscale" the concept in order to make it applicable in such contexts, by focusing on specific issues according to the priorities of the country and defined case by case.

Author Contributions: C.A.-R. and P.H. have been directly involved in the Libyan case study described in this article. They also worked together, back in the day, on the formulation of VTT's EcoCity concept to respond to the needs and challenges of developing countries. J.G.-N. has coordinated this study, critically reviewed the manuscript and provided useful recommendations.

Acknowledgments: The findings presented here have originated from the experience of a number of EcoCity projects and activities around the world funded by different sources. The costs to publish this article in open access are covered by VTT Technical Research Centre of Finland Ltd. The authors wish to thank all VTT colleagues involved in the activities discussed in this article; all Libyan institutions involved in the Libyan case study; and very specially the reviewers, for their valuable insights and suggestions.

Conflicts of Interest: The authors declare no conflict of interest.

\section{References}

1. United Nations, Department of Economic and Social Affairs, Population Division. The World's Cities in 2016. Data Booklet (ST/ESA/ SER.A/392). 2016. Available online: http://www.un.org/en/development/ desa/population/publications/pdf/urbanization/the_worlds_cities_in_2016_data_booklet.pdf (accessed on 1 August 2018).

2. United Nations General Assembly. The New Urban Agenda Adopted by the United Nations Conference on Housing and Sustainable Urban Development (Habitat III). 21 November 2016. Available online: http://habitat3.org/wp-content/uploads/N1639668-English.pdf (accessed on 1 August 2018).

3. Nader, S. Paths to a low-carbon economy-The Masdar example. Energy Procedia 2009, 1, 3951-3958. [CrossRef]

4. Bullivant, L. Dongtan-A Shangri-La for Shanghai? Archit. Urban. 2007, 440, 122-127.

5. Rapoport, E. Utopian Visions and Real Estate Dreams: The Eco-city Past, Present and Future. Geogr. Compass 2014, 8, 137-149. [CrossRef]

6. Keeton, R. Rising in the East-Contemporary New Towns in Asia; SUN Architecture: Amsterdam, The Netherlands, 2011.

7. Saunders, T. Ecology and community design: Lessons from Northern European ecological communities. In Eco-City Dimensions: Healthy Communities, Healthy Planet; Roseland, M., Ed.; New Society Publishers: Gabriola Island, BC, Canada, 1997; pp. 113-124.

8. Antuña-Rozado, C.; García-Navarro, J.; Mariño-Drews, J. Facilitation Processes and Skills Supporting EcoCity Development. Energies 2018, 11, 777. [CrossRef]

9. Roseland, M. Dimensions of the eco-city. Cities 1997, 14, 197-202. [CrossRef]

10. Joss, S. Eco-Cities: The Mainstreaming of Urban Sustainability-Key Characteristics and Driving Factors. Int. J. Sustain. Dev. Plan. 2011, 6, 268-285. [CrossRef] 
11. Surja, A.; Shaw, R. "Eco-city" to "disaster-resilient eco-community": A concerted approach in the coastal city of Puri, India. Sustain. Sci. 2008, 3, 249-265. [CrossRef]

12. Wong, T.-C.; Yuen, B. Eco-City Planning: Policies, Practice and Design; Springer: Heidelberg, Germany, 2011.

13. Ecocity Builders. Ecocity Framework and Standards. Available online: https://ecocitystandards.org/ (accessed on 14 April 2019).

14. Kline, E. Planning and creating eco-cities: Indicators as a tool for shaping development and measuring progress. Local Environ. 2000, 5, 343-350. [CrossRef]

15. Jabareen, Y.R. Sustainable urban forms: Their typologies, models, and concepts. J. Plan. Educ. Res. 2006, 26, 38-52. [CrossRef]

16. Caprotti, F. Critical research on eco-cities? A walk through the Sino-Singapore Tianjin Eco-City, China. Cities 2014, 36, 10-17. [CrossRef]

17. Cugurullo, F. Exposing smart cities and eco-cities: Frankenstein urbanism and the sustainability challenges of the experimental city. Environ. Plan. A Econ. Space 2018, 50, 73-92. [CrossRef]

18. Antuña-Rozado, C.; García-Navarro, J.; Reda, F.; Tuominen, P. Methodologies Developed for EcoCity Related Projects: New Borg El Arab, an Egyptian Case Study. Energies 2016, 9, 631. [CrossRef]

19. Brundtland Commission. Our Common Future; Oxford University Press: Oxford, UK, 1987.

20. United Nations Conference on Environment and Development (UNCED). The Rio Declaration on Environment and Development. Conference Report; UNCED: Rio de Janeiro, Brazil, 1992.

21. United Nations General Assembly. Transforming Our World: The 2030 Agenda for Sustainable Development; United Nations: New York, NY, USA, 2015.

22. The Finnish National Commission on Sustainable Development. The Finland We Want 2050-Society's Commitment to Sustainable Development; FNCSD: Helsinki, Finland, 2016.

23. Howard, E. Garden Cities of Tomorrow; Swan Sonnenschein \& Co.: Bath, UK, 1898.

24. Tuomi, T. Tapiola: A History and Architectural Guide; Espoo City Museum: Espoo, Finland, 1992.

25. Hertzen, H.V.; Spreiregen, P.D. Building a New Town: Finland's New Garden City, Tapiola; MIT Press: Cambridge, MA, USA, 1971.

26. Tuomi, T.; Paatero, K. Tapiola: Life and Architecture; Housing Foundation in Cooperation with the City of Espoo: Espoo, Finland, 2003.

27. Bindels, E.; Christiaanse, K.; Corneil, J.; Deplazes, A.; Henn, G.; Hoeger, K.; Hofland, E.; Magnago Lampugnani, V.; Natrup, W.; Oechslin, W.; et al. Campus and the City. Urban Design for the Knowledge Society; Hoeger, K., Christiaanse, K., Eds.; GTA Verlag: Zurich, Switzerland, 2007.

28. A GRID Start-Up and Accelerator Hub, Espoo, Finland. Available online: http://agrid.fi/ (accessed on 7 August 2018).

29. Aaltonen, T.; Gabrielsson, J.; Inkinen, R.; Majurinen, J.; Pennanen, A.; Wartiainen, K. Ecological Building Criteria for Viikki; Helsinki City Planning Publications: Helsinki, Finland, 1998.

30. Hakaste, H.; Jalkanen, R.; Korpivaara, A.; Rinne, H.; Siiskonen, M. Eco-Viikki. Aims, Implementation and Results; City of Helsinki, Ministry of the Environment: Helsinki, Finland, 2005; Available online: https://www.hel.fi/static/kanslia/uuttahelsinkia/Eco-Viikki_aims_implementation_results.pdf (accessed on 1 August 2018).

31. Siiskonen, M.; Eskola, T.; Rinne, H. Viikki Science Park and Latokartano Guide; Helsinki Plans 2010:8; Helsinki City Planning Department: Helsinki, Finland, 2010; Available online: https:/www.hel.fi/hel2/ksv/julkaisut/ esitteet/esite_2010-8_en.pdf (accessed on 1 August 2018).

32. Rodriguez, A.; Jaarto, P.; Vikström, K.; Aho, I. Eco-Viikki, Final Report of the Monitoring Project. (Originally in Finnish: Eco-Viikki, Seurantaprojektin loppuraportti); Helsingin Kaupunki Suunnittelu Virasto: Helsinki, Finland, 2004.

33. European Commission. White Paper on the Future of Europe; European Union: Brussels, Belgium, March 2017; Available online: https://ec.europa.eu/commission/future-europe/white-paper-future-europe_en (accessed on 7 April 2019).

34. European Commission. Towards a Sustainable Europe 2030; European Union: Brussels, Belgium, January 2019; Available online: https://ec.europa.eu/commission/publications/reflection-paper-towards-sustainableeurope-2030_en (accessed on 7 April 2019).

35. SITRA. Leading the Cycle. Finnish Road Map to a Circular Economy 2016-2015. Available online: https: //media.sitra.fi/2017/02/28142644/Selvityksia121.pdf (accessed on 7 August 2018). 
36. Ruosteenoja, K.; Jylhä, K.; Kämäräinen, M. Climate projections for Finland under the RCP forcing scenarios. Geophysica 2016, 51, 17-50.

37. Register, R. Ecocity Berkeley: Building Cities for a Healthy Future; North Atlantic Books: Berkeley, CA, USA, 1987.

38. Newman, P.; Beatley, T.; Boyer, H. Resilient Cities; Island Press: Washington, DC, USA, 2009.

39. Maclaren, V. Urban Sustainability Reporting. J. Am. Plan. Assoc. 1996, 62, 184-202. [CrossRef]

40. Wong, T.-C. Eco-cities in China: Pearls in the sea of degrading urban environments? In Eco-City Planning: Policies, Practice and Design; Wong, T.-C., Yuen, B., Eds.; Springer: London, UK, 2011; pp. 131-150.

41. Brown, A. Just Enough: Lessons in Living Green from Traditional Japan; Kodansha International: Tokyo, Japan, 2009.

42. Joss, S.; Molella, A.P. The Eco-City as Urban Technology: Perspectives on Caofeidian International Eco-City (China). J. Urban Technol. 2013, 20, 115-137. [CrossRef]

43. Masdar City, Abu Dhabi, UAE. Available online: https://masdar.ae/ (accessed on 9 October 2018).

44. Yigitcanlar, T.; Lee, S.H. Korean ubiquitous-eco-city: A smart-sustainable urban form or a branding hoax? Technol. Forecast. Soc. Chang. 2014, 89, 100-114. [CrossRef]

45. Low, M. Eco-Cities in Japan: Past and Future. J. Urban Technol. 2013, 20, 7-22. [CrossRef]

46. Shwayri, S.T. A Model Korean Ubiquitous Eco-City? The Politics of Making Songdo. J. Urban Technol. 2013, 20,39-55. [CrossRef]

47. Birds Korea. Available online: http://www.birdskorea.org/Habitats/Wetlands/Songdo/BK-HA-Songdo-Tidalflat-reclamation-2009-03.shtml (accessed on 12 November 2018).

48. Sharifi, A. From Garden City to Eco-urbanism: The quest for sustainable neighbourhood development. Sustain. Cities Soc. 2016, 20,1-16. [CrossRef]

49. Holden, M.; Li, C. The emergence and spread of eco-urban developments around the world. In Proceedings of the 4th World Sustainability Forum (WSF-2014), Basel, Switzerland, 1-30 November 2014.

50. Bond, A.; Morrison-Saunders, A.; Howitt, R. Sustainability Assessment: Pluralism, Practice and Progress; Routledge: New York, NY, USA, 2013.

51. Nieminen, J.; Lahti, P.; Nikkanen, A.; Mroueh, U.-M.; Tukiainen, T.; Shemeikka, J.; Huovila, P.; Pulakka, S.; Guangyu, C.; Nan, S.; et al. Miaofeng Mountain Town EcoCity; VTT Research Notes; VTT Technical Research Centre of Finland: Helsinki, Finland, 2010; 249p.

52. Cugurullo, F. How to build a sandcastle: An analysis of the genesis and development of Masdar city. J. Urban Technol. 2013, 20, 23-37. [CrossRef]

53. Ministry for Foreign Affairs. Development Policy and Development Cooperation. Available online: https://um.fi/goals-and-principles-of-finland-s-development-policy (accessed on 13 January 2019).

54. Development Policy Committee. Finland's Development Policy in 2018. From Myth to Grounded ParadigmFinland as a Defender of Equality for Women and Girls in Developing Countries; Development Policy Committee: Helsinki, Finland, 2018.

55. United Nations Environment Programme. Building for the Future. A United Nations Building Showcase in Nairobi; UNEP Division of Communications and Public Information: Nairobi, Kenya, 2011.

56. Yu, L. Low carbon eco-city: New approach for Chinese urbanization. Habitat Int. 2014, 44, 102-110. [CrossRef]

57. Flynn, A.; Yu, L.; Feindt, P.; Chun, C. Eco-cities, governance and sustainable lifestyles: The case of the Sino-Singapore Tianjin Eco-City. Habitat Int. 2016, 53, 78-86. [CrossRef]

58. Leyden, K.; Goldberg, A.; Michelbach, P. Understanding the Pursuit of Happiness in Ten Major Cities. Urban Aff. Rev. 2011, 47, 861-888. [CrossRef]

59. Shoval, N. Urban planning and tourism in European cities. Tour. Geogr. 2018, 20, 371-376. [CrossRef]

60. Lye, L.; Chen, G. Some thoughts on the development of eco-cities in Asia. In Towards a Liveable and Sustainable Urban Environment: Eco-Cities in East Asia; Lye, L., Chen, G., Eds.; World Scientific Publishing: Singapore, 2010; pp. 57-90.

61. Myllylä, S.; Kuvaja, K. Societal premises for sustainable development in large southern cities. Glob. Environ. Chang. 2005, 15, 224-237. [CrossRef] 
62. Piew, P.C.; Neo, H. Eco-Cities Need to Be Based around Communities, not Technology (Online Article). China Dialogue. 21 October 2013. Available online: https://www.chinadialogue.net/article/show/single/en/ 6427-Eco-cities-need-to-be-based-around-communities-not-technology (accessed on 18 March 2019).

63. Nagendra, H.; Bai, X.; Brondizio, E.S.; Lwasa, S. The urban south and the predicament of global sustainability. Nat. Sustain. 2018, 1, 341-349. [CrossRef]

(C) 2019 by the authors. Licensee MDPI, Basel, Switzerland. This article is an open access article distributed under the terms and conditions of the Creative Commons Attribution (CC BY) license (http://creativecommons.org/licenses/by/4.0/). 